\title{
University Challenge: Division, Discourse and Democracy
}

\section{Ronald Barnett ${ }^{1}$}

Published online: 23 April 2019

(C) Springer Nature Switzerland AG 2019

As is well known, a referendum was held in the UK in 2016 so that its peoples could express their preferences as to whether the UK should remain a member of the European Union (a political and economic association of 27 countries). The result produced more or less equal preferences for 'leave' and 'remain'-with the 'leave' vote narrowly exceeding the 'remain' vote (in the ratio of 52\%:48\%). It turned out that the single most influential factor in the voting pattern was that of higher education, with graduates having a significantly higher propensity to vote one way (to remain) and nongraduates to vote the other way (to leave).

It is evident then that the UK is not only split but also that 'higher education is the predominant factor dividing the nation' (Zhang 2018). This set of phenomenapolarisation in society and higher education being a significant influence in that polarisation - is almost certainly not unique to the UK. It is generally associated with the rise of popularism on the right, a strident neo-liberalism, and increasing levels of poverty and disaffection from mainstream politics and economic development.

There is a further set of phenomena here. Populist political leaders are heard to dissociate themselves from, and to discourage attention being given to, those with attested expertise. 'We've had enough of experts' was a point made by one such politician in the UK at the time of the EU referendum. Such sentiments, when played up and driven forward by a populist press, implicitly tend to encourage a mistrust of those in the more privileged parts of society, characteristically portrayed as 'elites'. This mistrust spills over onto universities, not least in a climate in which the very category of truth comes to be a matter of dispute, so giving rise to a 'post-truth' age, where there can be 'alternative facts'. (The term 'post-truth' was the Oxford Dictionary term of the year in 2016.)

Political concern on the right with universities is growing and is taking explicit form. In a draft political agenda statement, the Texas Republican Party explicitly set out its intention to ban critical thinking in universities. Although that declaration was later

Ronald Barnett

ron.barnett@ucl.ac.uk

1 University College London Institute of Education, London, UK 
rescinded, its underlying orientation towards universities is reflected in increasing concerns on the right with the 'liberal' character of universities. Legitimate concerns with the shouting down or no-platforming of speakers may be suspected of being deployed as cover for the voicing of right-wing views associated with the limitation of human freedoms.

In sum, universities - not least in democratic societies but in other societies as well - are now irrevocably entangled with social division. Moreover, this situation is worsening. Across the world, both in dictatorships and in democracies now subject to a rise of right-wing popularism, the university is accused of promoting a left-oriented outlook. It is noticed that graduates emerge from universities who critique public policies and social institutions and who take up positions in the public sphere. As intimated, universities and their members and their graduates are positioned as part of the 'elites' controlling public and political decision-making, with the term 'elites' becoming a term of abuse.

We have before us, therefore, a situation in which universities find themselves being placed in multiple jeopardy. Firstly, for most of their history, universities held a position on the fringe of society and were peripheral to the public interest. Now, in a situation in which more or less half of a population enjoys a higher education experience, the result is a fundamental and new social cleavage in which higher education supersedes social class or gender or ethnicity as the major determinant of social division. Secondly, universities are being positioned - in many countries - as part of the 'other', to be distrusted and critiqued or even directly attacked. Thirdly, the public sphere is riven, with universities speaking just to certain portions of it and seen as irrelevant or, worse still, working in their own sectional interests.

Present in all of this is a determination on the left is that universities should be understood as a crucial element in the forging not only of modernity but also of democracy itself. Higher education offered a means of social mobility for those from relatively impoverished backgrounds. Many proudly came to project themselves as 'the first in my family to go to university'. More formally, this aspirational sighting of higher education came to be taken up in the trope of 'social justice', a position that was often explicitly part of social-democratic policy-formation. As far back as the 1960s, a major report by the state into higher education in the UK considered it to be an 'axiom' that higher education should be available to all who could benefit from it (Cmnd 2154 1963: 8).

However, the linking of higher education and democracy has gone beyond that of increasing life chances. In particular, higher education has been seen as a vehicle for enabling society to become more open and rational. This reading connects higher education with citizenship, which goes beyond the matter of graduates becoming active in local, national and even global affairs. It also has its eye on the formation of the public sphere, in which society becomes a kind of debating society, with a rational and carefully considered debate playing itself out, governed only by — in Habermas' (1984) telling phrasing - 'the force of the better argument'. The give and take of reasons, the search for and analysis of evidence, a concern with truthfulness, a collective will to get to the bottom of things and an understanding that matters of public concern are highly complex and warrant the intermingling of many voices and approaches: these are just some of the elements of a public sphere, and it is evident, if such a public sphere is fully to emerge, that universities have multiple roles to play. 
These considerations serve to make more problematic still the social division with which universities are associated. In part, this social division arises from the sheer fact of participation in higher education. (In the UK referendum, it is evident that families were split, not least through the association of family members having experienced, or not, higher education.) This social division is connected with quite different opportunities in the labour market that higher education affords, both in the home country and, moreover, globally. In the global economy, the university graduate is potentially highly mobile. But there is also now, and even more fundamentally, a discursive cleavage in society, with which the university is deeply associated.

The modern world is doubly complex. On the one hand, its institutions, systems, economies and procedures now intermesh with a turbulence that produces unpredictable outcomes. Images of interwoven spaghetti or seaweed are insufficient to do justice to this instability, for it has a dynamic that is ever on the move, a global dynamic with added speed in a digital age (Virilio 2005). This is a complex situation in one of its technical meanings, in that this openness presents a radical uncertainty beyond algorithmic calculation.

However, to this complexity must be added supercomplexity (Barnett 2000). This is a yet higher-level complexity, in which the very categories through which humans try to gain a grip on the world in which they are placed are disputable. This was one of the battle-cries of postmodernism, the loss of the grand narratives (Lyotard 1984). Now, we have no sure way of even beginning to understand the world. All readings are open to dispute and - deep-down - everyone knows that to be the case. Ultimately, this is not just a matter of cognitive uncertainty for supercomplexity presents continuing challenges to one's identity. In a world that is discursively contested, personal identity becomes fluid.

Higher education is crucial here, and in two ways. Firstly, it has helped to create this situation, especially that of supercomplexity, for it has spawned new ideas, understandings and frameworks that are manifestly in dispute. The university has helped to bring about this age of supercomplexity. Secondly, the education with which it is associated is, as it turns out, an education brilliantly designed to enable individuals to cope with supercomplexity. The giving and taking of reasons, coming to an awareness that there are many perspectives on an issue, being able to see different sides of an argument, realising that one's own views may be critiqued, and becoming aware that a new set of ideas may come along tomorrow that may upset the apple-cart: all these are part of a higher education as it has developed (at least in many universities across the world) and they are supremely appropriate virtues for living amid supercomplexity. To put it crudely, a genuine higher education is a superb vehicle for living with uncertainty, both cognitively and in one's very being.

This, then, is the situation in front of us: an incredibly complex world, full of uncertainty, openness and disputatiousness, in which universities are doubly implicated. They have helped to bring about this changing world, full of complexity and discursive supercomplexity and they have developed an education that equips its members to handle this uncertainty.

The recent UK referendum result, then, should have come as no surprise. By and large, those who had experienced higher education and university life were in favour of a globally open world of challenge, not just economically but politically and in handling fluid identities. Those who had not experienced higher education were much 
more likely to hanker, as they saw it, for a past situation in which matters were much simpler and clearer (in which Great Britain was 'great', had a secure place in the world, and life was more straightforward, and personal identity was both more stable and carried a global status ('Great' Britain)). It is telling that among the favoured tropes of those who voted to leave the EU are those of World War II, past victories, Empire and so forth. Even the former colour of the UK's passport came into play as an emblem of past distinctiveness. Just published, too, is a report in which 54\% of the UK's population wish to see a strong leader 'who is willing to break the rules' and ignore parliamentary sovereignty, a figure — we may presume — who can bring simplicity and order to a situation of extreme complexity (Hansard Society 2019).

We are faced, then, with a situation in which society is gravely divided, as between those who have and have not experienced higher education; and with understandable antagonism between the two parties. The phrase 'cultural war' is fully justified to describe this situation for what we have here are different peoples attempting to secure their hegemony in a restricted — and, yes, embattled — discursive space.

A key question that arises here is this: what is the responsibility of the university in this situation and what are its possibilities - a situation in which the university is, to a significant extent, culpable; and there are four continuing possibilities. Firstly, the university should, with much more fervour than hitherto, strive to admit students from lower socio-economic backgrounds. This means, at a minimum, admitting $70 \%$ of younger people in one way or another (whether on apprenticeship degrees, on digital platforms, in short programmes, in association with community colleges or whatever), such that a definite majority of the population can experience higher education. (Several countries are already at this level and others are aspiring in this direction.)

Secondly, the university should reflect on itself so as to understand its own inner resources for educating for a world of persistent uncertainty, both in its systems and in what it is to be human amid radical instability. In the process, old ideas of Bildung and liberal education need to be jettisoned, if such an educational programme is to be brought off. The university is already achieving this but this far-reaching kind of education for a globalised age now needs to be accomplished more systematically, intently and fervently. Again, some universities have set out to do just this.

Thirdly, the university should be deploying its resources to reach out to the wider world in all manner of ways to help to develop the public sphere. This means listening to and engaging with multiple publics (plural) in comprehensible ways, so as to enlarge public debate, not least on matters of complex decision-making. Such an outwardfacing stance will go against the grain for many universities and their members, which are much more used to speaking in their own idioms and in their own 'tribes and territories' (Becher 1990).

Fourthly, universities collectively, within national systems and whether public or private institutions, should accept the drawing up of a 'compact' (NCIHE 1997), agreed with their host state on a regular basis, as a condition of being granted university status. In this compact, universities individually would spell out what they were willing to do for the nation and for the world, not least in the formation of a better-informed civic conversation.

The title of this article is 'University challenge: division, discourse and democracy' and it is evident that universities are faced with this triple challenge of social division, multiple discourses and an impaired democracy. It is evident, too, surely, that the 
university has both responsibilities and possibilities in playing its part in addressing these challenges which, after all, confront the whole of society.

\section{References}

Barnett, R. (2000). Realizing the university in an age of supercomplexity. Buckingham: Open University Press \& SRHE.

Becher, T. (1990). Academic tribes and territories. Stony Stratford: Open University Press \& SRHE.

Cmnd 2154. (1963). Higher education. Report of the Committee on Higher Education appointed by the Prime Minister under the Chairmanship of Lord Robbins. London: HMSO.

Habermas, J. (1984). The theory of communicative action: reason and the rationalization of society. Cambridge: Polity.

Hansard Society (2019). Audit of political engagement 16. https://assets.ctfassets.net/rdwvqctnt75b/7 iQEHtrkIbLcrUkduGmo9b/cb429a657e97cad61e61853c05c8c4d1/Hansard-Society_Audit-of-PoliticalEngagement-16 2019-report.pdf. Accessed 13 April 2019.

Lyotard, J-F. (1984). The Postmodern Condition: A Report on Knowledge. Manchester: University of Manchester.

NCIHE. (1997). Higher Education in the Learning Society. Report of the Committee of Inquiry chaired by Sir (later Lord) Ron Dearing. London: HMSO.

Virilio, P. (2005). Negative horizon. London and New York: Continuum.

Zhang, A. (2018). New findings on key factors influencing the UK's referendum on leaving the EU. World Development, 102(February), 304-314. https://doi.org/10.1016/j.worlddev.2017.07.017. 